\title{
Green Synthesis of Renewable Dimethyl Terephthalate-Like Monomer from Eugenol
}

(Sintesis Hijau Dimetil Diperbaharu Tereftalat Seakan Monomor daripada Eugenol)

\author{
Maulidan Firdaus*, Triana Kusumaningsih, Atmanto Heru Wibowo \& Carissa Hertiningtyas
}

\begin{abstract}
Dimethyl terephthalate, a diester monomer derived from petroleum-based resources, plays important role in the production of polyester such as polyethylene terephthalate (PET), resins for polyester, fibres, and films as well as engineering polymers. High demand on PET together with environmental concerns require to find alternative for renewable monomers urgently whenever or wherever to substitute the exhausting crude oil-based monomers. A simple and highly efficient method to prepare PET analogue monomer, methyl 2-[2-methoxy-4-[3-(2-methoxy-2-oxoethyl)] thiopropyl]phenoxy acetate (4), from renewable eugenol is described. The key step involves successive Williamson etherification, esterification, to be followed by thiol-ene reaction. Remarkably, it turned out that the thiol-ene reaction has proven to be effective in the introduction of the ester group to the olefinic substrate without the use of solvent and initiator leading to diester 4. The technique offered here comprises advantages i.e. excellent yields, mild reaction condition, and easy to perform, thus, provide a sustainable alternative to synthesize diester from eugenol.
\end{abstract}

Keywords: Dimethyl terephtalate-like; esterification; eugenol; thiol-ene addition; Williamson etherification

\section{ABSTRAK}

Dimetil tereftalat ialah monomer diester yang diterbitkan daripada sumber berasaskan petroleum, memainkan peranan penting dalam penghasilan poliester seperti polietilena tereftalat (PET), resin untuk poliester, serat dan filem serta polimer kejuruteraan. Permintaan tinggi ke atas PET serta kebimbangan persekitaran memerlukan pencarian alternatif monomer diperbaharu secepat mungkin untuk menggantikan minyak mentah berasaskan monomer yang semakin berkurangan. Kaedah yang mudah serta cekap untuk menyediakan monomer analog PET, metil 2-[2-metoksi-4-[3-(2- metoksi-2-oksoetil)]tiopropil]fenoksi asetat (4), daripada eugenol diperbaharu telah dicirikan. Langkah penting melibatkan eterifikasi Williamson secara berturutan, esterifikasi dan diikuti oleh reaksi tiol-ena. Menariknya, ternyata reaksi thiol-ena terbukti berkesan dalam memperkenalkan kumpulan ester kepada substrat olefinik tanpa menggunakan pelarut dan pemula yang menghasilkan diester 4. Teknik yang digunakan memberikan kelebihan seperti hasil yang tinggi, keadaan tindak balas yang sederhana dan mudah dijalankan, dengan memberikan alternatif diperhabaru untuk mensintesis diester daripada eugenol.

Kata kunci: Dimetil tereftalat-analog; esterifikasi; eugenol; penambahan thiol-ena; reaksi eterifikasi Williamson

\section{INTRODUCTION}

One of the main plastics wastes is polyethylene terephthalate (PET) with estimated worldwide production of 30.3 million tons in 2017 (Gomes et al. 2019). PET is mainly utilized for packaging material and textile production and it became popular in the production of disposable soft drink bottles because of its enviable properties such as transparency, innocuity, durability, and strength. PET can occur both as a transparent (amorphous) and as a white and opaque (semi-crystalline) material depending on its thermal property and processing (Jankauskaite et al. 2008). It can be synthesized through polycondensation reaction by either transesterification between ethane-1,2diol and dimethyl terephthalate or esterification between terephthalic acid and ethane-1,2-diol (Nadkarni 2002). The increasing use of PET in circulation poses an unintended hazard to the environment (Abdullah \& Ahmad 2013). It significantly disturbs and damages the ecosystem because this non-degradable material is difficult to decompose and having high resistance to atmospheric and biological substances (Nabil et al. 2012). Moreover, at present, PET is mostly manufactured from petroleum-based resources. Due to the large production volume and huge consumptions of PET, it is urgently needed to find renewable substituents of 
dimethyl terephthalate. As a renewable aromatic monomer, eugenol is suitable candidate to resolve this problem and has the impending to substitute the fossil-based monomers, which are at present extensively employed in the field of polyesters.

Eugenol, plentiful plant constituent of lignin apart from vanillin, is promising renewable starting material. It naturally occurs in clove, cinnamon, tulsi, and pepper plants (Khalil et al. 2017). Eugenol contains reactive groups i.e. allyl, hydroxyl, and/or methoxy. The hydroxy group on eugenol could be transformed into ether through the Williamson etherification reaction. In addition, the existence of allyl group could be modified using the thiol-ene reaction. Thiol-ene reaction, in convinced conditions, is commonly a very appropriate technique for various modifications, which permit an efficient way to introduce diverse functional groups to olefinic compounds (Firdaus 2017; Firdaus et al. 2011). In addition to be orthogonal and metal free, in certain cases, thiol-ene reactions can be well thought-out as click reaction because this reaction accomplishes utmost of the click standards for example presence highly effective processes, easy to accomplish, and arranged fast into high yield (Dondoni 2008). Thiol-ene reactions employing eugenol as olefinic substrate have been reported i.e. synthesis of thiol-ene crosslinker from eugenol (Guzmán et al. 2019, 2017), synthesis of mussel-inspired polymers from eugenol (Alhaffar et al. 2019). In an attempt to synthesize dimethyl terephthalate like monomer, thiol-ene reaction in eugenol has been reported by Hu et al. (2015a, 2015 b) which both introduced methyl thioglycolate into its allyl group using 2,2-dimethoxy-2-phenylacetophenone (DMPA) as a photoinitiator and Dai et al. (2016) used 3-mercaptopropionic acid, thiomaleic acid and DMPA. Although the reported methods gave good yields, the use of DMPA, solvents, and ultraviolet irradiation are not recommendable from an environmental perspective. In this work, dimethyl terephthalate like monomer is prepared from renewable eugenol via thiol-ene reaction without the use of initiator and solvent and subsequent Williamson etherification and esterification.

\section{EXPERIMENTAL DETAILS}

\section{MATERIALS AND INSTRUMENTS}

Eugenol, $\mathrm{NaOH}$, Chloroacetic acid, $\mathrm{HCl}$ (37\%), Methanol, $\mathrm{H}_{2} \mathrm{SO}_{4}, \mathrm{NaOH}_{3}, \mathrm{Na}_{2} \mathrm{SO}_{4}$ anhydrous were purchased from Merck. Methyl thioglucolate (Sigma Aldrich) was used as received. All technical grades solvents were redistilled before used. Thin layer chromatography (TLC) was done using silica gel TLC cards (Merck) with layer thickness $0.20 \mathrm{~mm}$. $\mathrm{KMnO}_{4}$ reagents were used as visualization reagent. Column chromatography was carried out using Silica Gel 60 (Merck) and all eluents were technical grade without purification before used. FTIR spectra were set down on Shimadzu Prestige 21 FTIR spectrophotometer. ${ }^{1} \mathrm{HNMR}$ and ${ }^{13} \mathrm{C}$ NMR spectra were recorded on Agilent VNMR spectrometers working at $400 \mathrm{MHz} .{ }^{1} \mathrm{H}$ NMR spectra were described in ppm relative to TMS $(\delta=0.00$ $\mathrm{ppm}$ ) or to the solvent signal for $\mathrm{CDCl}_{3}$ at $7.26 \mathrm{ppm}$, and ${ }^{13} \mathrm{CNMR}$ spectra were described in ppm relative for deuterated chloroform at $77.00 \mathrm{ppm}$.

\section{EXPERIMENTAL PROCEDURES}

PREPARATION OF 2-(4-ALLYL-2-METHOXYPHENOXY)ACETIC ACID (2)

Eugenol $(\mathbf{1}, 0.03 \mathrm{~mol})$ was put into a $100 \mathrm{~mL}$ three neck flask and $17.5 \mathrm{~mL}$ of $33 \% \mathrm{NaOH}$ solution was added. The mixture was stirred magnetically for $30 \mathrm{~min}$, and $12.5 \mathrm{~mL}$ of $50 \%$ chloroacetic acid solution was dropped using a separating funnel. The reaction mixture was then heated at $85^{\circ} \mathrm{C}$ for $2 \mathrm{~h}$. The mixture was allowed to cool and acidified with $6 \mathrm{M} \mathrm{HCl}$ to $\mathrm{pH} 1$ and decanted. Hot distilled water was added to the precipitate and waited for crystal to form. The crystals were removed by filtration and recrystallized using hot water to afford 2 . White crystalline needle; yield 83\%; m.p. 97-98 ${ }^{\circ} \mathrm{C}$ ((Labarrios et al. 1999) 98-99 $\left.{ }^{\circ} \mathrm{C}\right)$; FTIR 11(KBr) 3300-2500, 1753, 1639, 1518, 1256, 1233, 1163, 1031, 912, $814 \mathrm{~cm}^{-1} .{ }^{1} \mathrm{HNMR}\left(400 \mathrm{MHz}, \mathrm{CDCl}_{3}\right) \delta$ $6.82(\mathrm{~d}, J=8.1 \mathrm{~Hz}, 1 \mathrm{H}), 6.76-6.69(\mathrm{~m}, 2 \mathrm{H}), 6.00-5.87$ (m, 1H), $5.08(\mathrm{dd}, J=12.0,6.1 \mathrm{~Hz}, 2 \mathrm{H}), 4.65$ (s, 2H), $3.86(\mathrm{~s}, 3 \mathrm{H}), 3.33$ (d, $J=6.7 \mathrm{~Hz}, 2 \mathrm{H}) \mathrm{ppm}$, (carboxylic acid group proton was not detected). ${ }^{13} \mathrm{CNMR}(100 \mathrm{MHz}$, $\mathrm{CDCl}_{3}$ ) $\delta 172.96,149.54,145.44,137.34,135.41,120.89$, $116.04,115.67,112.68,67.32,55.96,39.90 \mathrm{ppm}$. These spectral data are in accordance with those reported by Buckler et al. (2017) and Labarrios et al. (1999).

\section{PREPARATION OF METHYL 2-(4-ALLYL-2- METHOXYPHENOXY)ACETATE (3)}

Into a $100 \mathrm{~mL}$ round bottom flask was added 0.009 moles of 2, 0.423 moles of methanol and 11 drops of concentrated sulphuric acid. The mixture was refluxed at $65^{\circ} \mathrm{C}$ for $6 \mathrm{~h}$. Subsequently, the mixture was evaporated and extracted with $20 \mathrm{~mL}$ distilled water and $20 \mathrm{~mL}$ dichloromethane. The extracted dichloromethane layer was added with 10 $\mathrm{mL}$ saturated $\mathrm{NaHCO}_{3}$ solution, washed with distilled $\mathrm{H}_{2} \mathrm{O}$ and dried using anhydrous $\mathrm{Na}_{2} \mathrm{SO}_{4}$. The solvent was evaporated to give 3. Light brown liquid yield $91 \%$. FTIR (KBr) 1763, 1638, 1592, 1513, 1436, 1261, 1204, $1145,1074,915,805 \mathrm{~cm}^{-1}$. ${ }^{1} \mathrm{HNMR}\left(400 \mathrm{MHz}, \mathrm{CDCl}_{3}\right) \delta$ $6.76(\mathrm{~d}, J=8.1 \mathrm{~Hz}, 1 \mathrm{H}), 6.73(\mathrm{~d}, J=1.7 \mathrm{~Hz}, 1 \mathrm{H}), 6.68$ $(\mathrm{dd}, J=8.1,1.9 \mathrm{~Hz}, 1 \mathrm{H}), 5.94(\mathrm{ddt}, J=16.9,10.1,6.7$ $\mathrm{Hz}, 1 \mathrm{H}), 5.12-5.02(\mathrm{~m}, 2 \mathrm{H}), 4.66(\mathrm{~s}, 2 \mathrm{H}), 3.86(\mathrm{~s}, 3 \mathrm{H}), 3.78$ (s, 3H), $3.32(\mathrm{~d}, J=6.7 \mathrm{~Hz}, 2 \mathrm{H}) \mathrm{ppm} .{ }^{13} \mathrm{CNMR}(100 \mathrm{MHz}$, $\left.\mathrm{CDCl}_{3}\right) \delta 169.73,149.61,145.59,137.49,134.65,120.48$, $115.89,114.56,112.59,66.74,55.92,52.26,39.91 \mathrm{ppm}$. 
These spectral data matched with the reported literature (Labarrios et al. 1999).

\section{SYNTHESIS OF METHYL 2-[2-METHOXY-4-[3-(2-METHOXY-2- OXOETHYL)]THIOPROPYL]PHENOXY ACETATE (4)}

Into a $5 \mathrm{~mL}$ round bottom flask was added 0.002 moles 3 and 0.024 moles of methyl thioglycolate. The mixture was stirred magnetically at room temperature for $24 \mathrm{~h}$. The progress of the reaction was observed using TLC (hexane: ethyl acetate $=7: 3$ ). Reaction products were purified by column chromatography using $250 \mathrm{~mL}$ (n-hexane: ethyl acetate $=9: 1$ ) and $350 \mathrm{~mL}$ (hexane: ethyl acetate $=7: 3$ ) to afford 4. Colorless liquid yield 91\%. FTIR (neat) 2951, 1756, 1734, 1512, 1272, 1145, 1006, 766, $632 \mathrm{~cm}^{-1} .{ }^{1} \mathrm{HNMR}$ $\left(400 \mathrm{MHz}, \mathrm{CDCl}_{3}\right) \delta$ 6.76-6.64 (m, 3H), $4.65(\mathrm{~s}, 2 \mathrm{H}), 3.86$ $(\mathrm{s}, 3 \mathrm{H}), 3.77(\mathrm{~s}, 3 \mathrm{H}), 3.71(\mathrm{~s}, 3 \mathrm{H}), 3.21(\mathrm{~s}, 2 \mathrm{H}), 2.68-2.59$ (dt $J=10.6,7.4 \mathrm{~Hz}, 4 \mathrm{H}$ ), $1.94-1.83$ (quint, $J=7.4 \mathrm{~Hz}$, $2 \mathrm{H}) \mathrm{ppm} .{ }^{13} \mathrm{CNMR}\left(100 \mathrm{MHz}, \mathrm{CDCl}_{3}\right) \delta 171.06,169.73$, $149.55,145.49,135.89,120,34,114,49,112,49,66,70$, $55,96,52,39,52,07,34,31,33,51,32,09,30,60$ ppm. These spectral data are in agreement with those described by Hu et al. (2015a, 2015b).

\section{RESULTS AND DISCUSSION}

With the main purpose to find suitable alternative of PET monomer, naturally occurring eugenol which contains allyl and phenolic hydroxyl groups has been utilized as renewable starting material for the synthesis of dimethyl terephthalate-like monomer (Scheme 1). Both the terminal double bond on the ally group and hydroxyl group provides an appealing route that makes it easy to be modified. In one hand, the phenolic hydroxyl group of eugenol provides perfect template in presenting ester functionalization through the Williamson etherification to be followed by esterification. On the other hand, the terminal olefinic group on eugenol offers faultless model in introducing an ester group via thiol-ene reaction. More precisely, the extensive reaction of both the allyl and hydroxyl groups of eugenol into ester groups would lead to suitable monomers for PET. It has been reported that the high efficiency of thiol ene reactions allow the introduction of different functionalities to alkenes (Firdaus \& Meier 2013a; Firdaus et al. 2011), makes it an appropriate method to afford eugenol-based monomers for the preparation of renewable PET analogue.<smiles>C=CCc1ccc(O)c(OC)c1</smiles>

SCHEME 1. Synthesis of $\mathbf{4}$ from eugenol 1

Taking this information, we started to introduce ester group on the phenolic hydroxyl group of eugenols through successive Williamson etherification and esterification reaction. The Williamson etherification of eugenol was carried out using chloroacetic acid as an alkyl halide and $\mathrm{NaOH}$ as base which functions to form a phenoxide ion. All reactants were heated at $85{ }^{\circ} \mathrm{C}$ and the reaction progress was checked by TLC (eluent hexane: ethyl acetate $=7: 3$ ) until the spot of eugenol vanished, indicating the accomplishment of the reaction. The reaction was completed for $2 \mathrm{~h}$ to give white crystalline needle $\mathbf{2}$ in $83 \%$ yield. Complete transformation of $\mathbf{1}$ to $\mathbf{2}$ was evidenced by FTIR and NMR analyses. FTIR spectra (Figure 1) showed the appearance of broad absorption from $\mathrm{OH}$ carboxylic acid groups at $3300-2500 \mathrm{~cm}^{-1}$ together with the $\mathrm{C}=\mathrm{O}$ group at $1753 \mathrm{~cm}^{-1}$ which thus provide sufficient confirmation for the formation of acid $\mathbf{2}$. The success of the Williamson etherification was also confirmed by ${ }^{1} \mathrm{H}$ and ${ }^{13} \mathrm{C}$ NMR analyses. A new signal at $4.65 \mathrm{ppm}$ referring to a methylene proton next to the carboxylic acid group appeared (Figure 2). Although the carboxylic acid group proton was not detected, based on ${ }^{13} \mathrm{C}$ NMR analysis, carbon signal corresponding to the carboxylic acid carbon appeared at $172.96 \mathrm{ppm}$.

The next step was esterification reaction of 2 using methanol and concentrated sulphuric acid catalyst. The reaction was performed at $65^{\circ} \mathrm{C}$ and completed for $6 \mathrm{~h}$ which was indicated by disappearance of acid 2 spot on 
TLC (eluent hexane: ethyl acetate $=7: 3$ ). FTIR spectra (Figure 1) displays the disappearance of hydroxyl group absorption at 3300-2500 $\mathrm{cm}^{-1}$ and the appearance of absorption peak at $1204 \mathrm{~cm}^{-1}$ which is a typical absorption of the $\mathrm{C}-\mathrm{O}$ ester group. The sharp absorption of the carbonyl group is shifted from 1753 to $1763 \mathrm{~cm}^{-1}$ which thus indicates that the carbonyl of carboxylic group changed into the ester carbonyl group. All of the peaks identified in the FTIR spectra are very compatible with the functional groups possessed by ester 3. ${ }^{1} \mathrm{H}$ NMR analysis of the product also revealed the successful of the esterification. In the ${ }^{1} \mathrm{H}$ NMR spectrum of 3 (Figure 2 ), the appearance of singlet peak at $3.78 \mathrm{ppm}$ which is ascribed to the methyl protons of the methyl ester group evidenced that the esterification was taken placed.

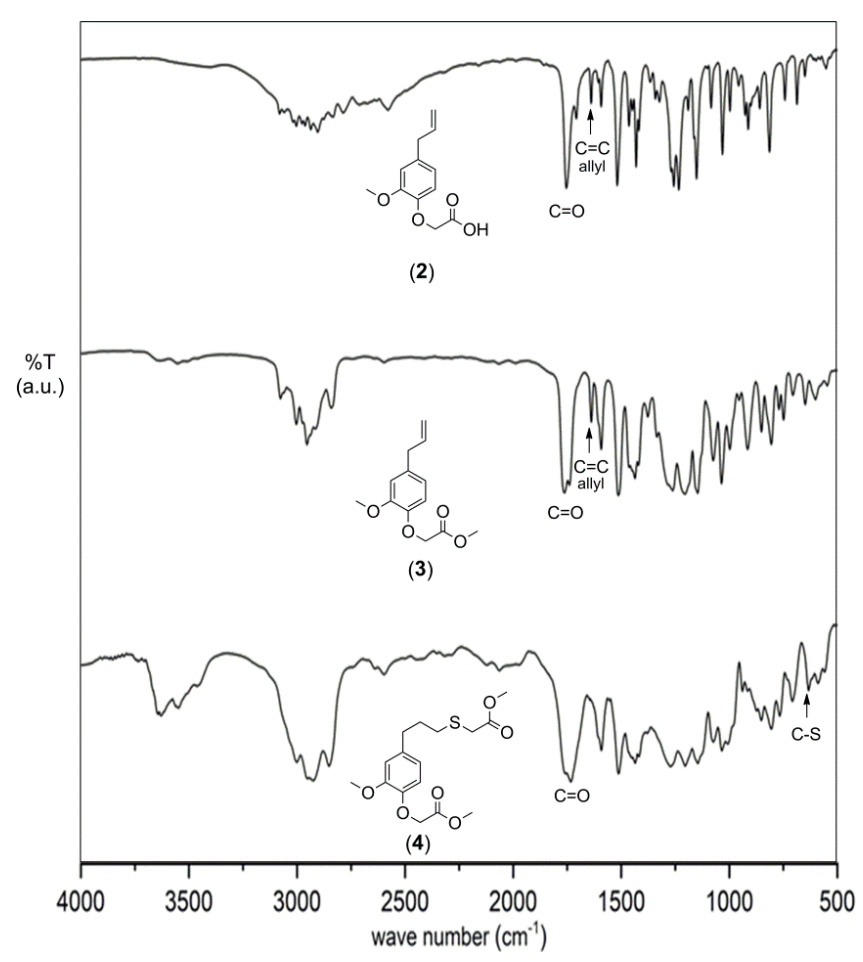

FIGURE 1. FTIR Spectra of acid 2, ester $\mathbf{3}$ and diester $\mathbf{4}$

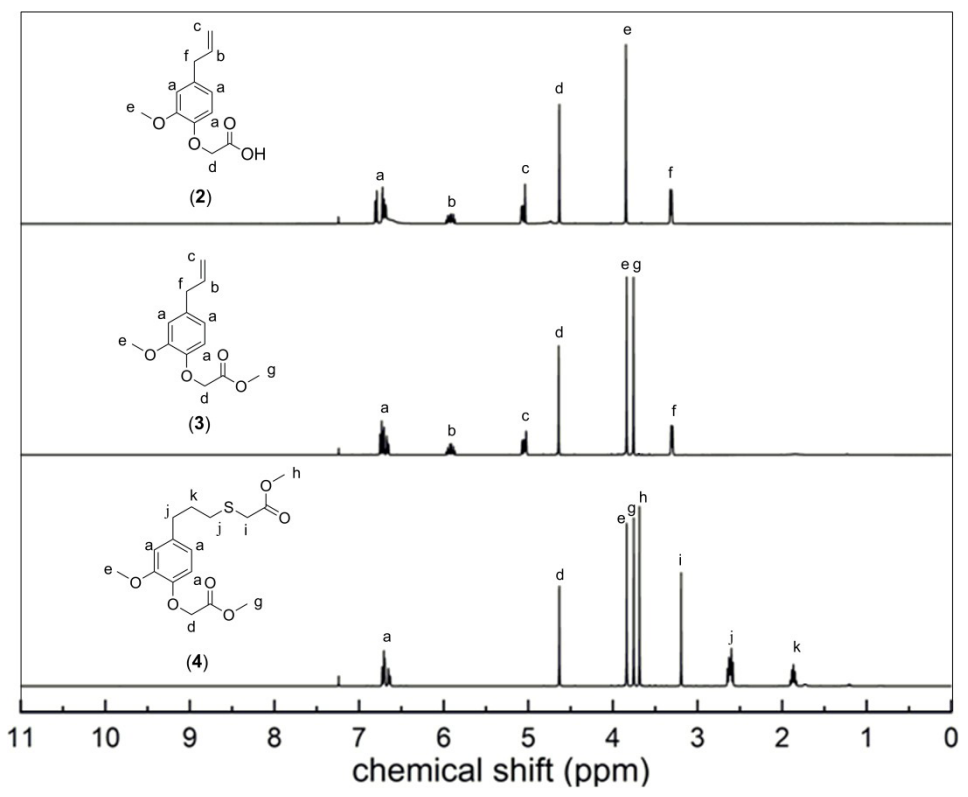

FIGURE 2. ${ }^{1} \mathrm{H}$ NMR spectra of acid $\mathbf{2}$, ester $\mathbf{3}$ and diester $\mathbf{4}$ 
Another promising effective modification of ester 3 would be to modify its double bond on the allyl group through thiol-ene reaction. In earlier reports, introductions of amine, hydroxyl, or methyl ester functionalized thiols to olefinic substrates led to appropriate monomers for polycondensation (Firdaus \& Meier 2013b; Firdaus et al. 2011). The simplicity of thiol-ene reactions, which can be carried out just mixing thiol and terminal double bond at room temperature without the use of solvent and initiator, makes it a useful approach for numerous chemical conversions. Having ester 3 in hand, we started our investigation on the addition of methyl thioglycolate into the double bond of the ester. In this study, the thiol-ene reaction was done simply by mixing ester 3 and methyl thioglycolate under solvent and radical initiator-free conditions at room temperature. In order to maximize the efficiency of the thiol-ene reactions, at first the ratio of compound $\mathbf{3}$ and methyl thioglycolate was optimized. The progress of the reaction was observed with TLC (eluent hexane: ethyl acetate $=7: 3$ ) until the spot of 3 disappear. A 1:1 ratio was initially employed for the thiol-ene reaction of $\mathbf{3}$ and methyl thioglycolate. However, the transformation of $\mathbf{3}$ into product was not completed even after $48 \mathrm{~h}$. The quantity of methyl thioglycolate was then increased to 1.2 equiv which thus a significant conversion was observed. After $24 \mathrm{~h}$, the spot of 3 was completely disappeared indicating the completion of the thiol-ene reaction. The use of excess methyl thioglycolate provided better results and after purification using column chromatography (eluent hexane: ethyl acetate $=9: 1$ and 7:3), gave colourless liquid diester 4 in $91 \%$ yield. FTIR and NMR analyses revealed the successful of the thiol-ene reaction. In the FTIR spectra (Figure 1), this is shown by the disappearance of the absorption of $\mathrm{C}=\mathrm{C}$ allyl group at $1638 \mathrm{~cm}^{-1}$ and the appearance of absorption $632 \mathrm{~cm}^{-1}$ which is assigned as C-S absorption. In addition, the complete disappearance of typical peaks of the double bond protons on allyl group at 5.12-5.02 and $5.94 \mathrm{ppm}$ on the ${ }^{1} \mathrm{H}$ NMR spectra (Figure 2) as well as newly emerged signal at $3.21 \mathrm{ppm}$ from methylene group and singlet at $3.71 \mathrm{ppm}$ from methoxy ester group, both from methyl thioglicolate, indicate the formation of the thioether functionality. Moreover, the ${ }^{13} \mathrm{C}$ NMR of product $\mathbf{4}$ also confirmed that methyl thioglycolate was successfully added to the compound $\mathbf{3}$.

It is worth to highlight that along with the simplicity of the thiol-ene reaction which can be carried out only by mixing the olefinic compound and methyl thioglycolate at room temperature under initiator and solvent-free condition, the sustainable use of renewable eugenol can be straightforward converted into diester monomer. Thus, the obtained monomer could be used as a valuable alternative diester to at-least-partially substitute the present petroleum- based dimethyl terephthalate. Overall, every step of the synthetic routes gave excellent yield.

\section{CONCLUSION}

In conclusion, we present an efficient and convenient way for the synthesis of dimethyl terephthalate like monomer from renewable eugenol through three steps. The first step was nucleophilic substitution of chloroacetic acid and eugenol using $\mathrm{NaOH}$ via Williamson etherification. The second step was esterification of 2-(4-allyl-2methoxyphenoxy)acetic acid (2) and methanol and the final step was thiol-ene reaction of methyl 2-(4-allyl2-methoxyphenoxy)acetate (3) and methyl thioglycolate under solvent and initiator-free condition. Etherification Williamson reaction, esterification and thiol-ene reaction yielded acid 2, ester 3 and diester 4 compound in 83\%, $91 \%$ and $91 \%$, respectively. These methods open the window for valuable alternative for the synthesis of diester being interesting mimics of dimethyl terephthalate.

\section{ACKNOWLEDGEMENTS}

M.F. thanks the Ministry of Research, Technology, and Higher Education of the Republic of Indonesia for financial funding in the form of PUPT2015 project.

\section{REFERENCES}

Abdullah, N.M. \& Ahmad, I. 2013. Fire-retardant polyester composites from recycled polyethylene terephthalate (PET) wastes reinforced with coconut fibre. Sains Malaysiana 42(6): 811-818.

Alhaffar, M.T., Akhtar, M.N. \& Ali, S.A. 2019. Utilization of catecholic functionality in natural safrole and eugenol to synthesize mussel-inspired polymers. RSC Advances 9(37): 21265-21277.

Buckler, J.N., Banwell, M.G., Kordbacheh, F., Parish, C.R., Santiago, F.S. \& Khachigian, L.M. 2017. Developing neolignans as proangiogenic agents: Stereoselective total syntheses and preliminary biological evaluations of the four guaiacylglycerol 8-O-4'-coniferyl ethers. ACS Omega 2(10): 7375-7388.

Dai, J., Jiang, Y., Liu, X., Wang, J. \& Zhu, J. 2016. Synthesis of eugenol-based multifunctional monomers via a thiol-ene reaction and preparation of UV curable resins together with soybean oil derivatives. RSC Advances 6(22): 17857-17866.

Dondoni, A. 2008. The emergence of thiol-ene coupling as a click process for materials and bioorganic chemistry. Angewandte Chemie Inernational Edition 47(47): 89958997.

Firdaus, M. 2017. Thiol-ene (click) reactions as efficient tools for terpene modification. Asian Journal of Organic Chemistry 6(12): 1702-1714.

Firdaus, M. \& Meier, M.A.R. 2013a. Renewable polyamides and polyurethanes derived from limonene. Green Chemistry 15(2): 370-380. 
Firdaus, M. \& Meier, M.A.R. 2013b. Renewable co-polymers derived from vanillin and fatty acid derivatives. European Polymer Journal 49(1) 156-166.

Firdaus, M., de Espinosa, L.M. \& Meier, M.A.R. 2011. Terpenebased renewable monomers and polymers via thiol-ene additions. Macromolecules 44(18): 7253-7262.

Gomes, T.S., Visconte, L.L. \& Pacheco, E.B. 2019. Life cycle assessment of polyethylene terephthalate packaging: An overview. Journal of Polymer and the Environment 27(3): 533-548.

Guzmán, D., Mateu, B., Fernández-Francos, X., Ramis, X. \& Serra, A. 2017. Novel thermal curing of cycloaliphatic resins by thiol-epoxy click process $\mathrm{w}$ i t h $\mathrm{s}$ e $\mathrm{v}$ e $\mathrm{r}$ a 1 multifunctional thiols. Polymer International 66(12): 16971707.

Guzmán, D., Serra, A., Ramis, X., Fernández-Francos, X. \& de la Flor, S. 2019. Fully renewable thermosets based on biseugenol prepared by thiol-click chemistry. Reactive and Functional Polymers 136: 153-166.

Hu, K., Zhao, D., Wu, G. \& Ma, J. 2015a. Synthesis and properties of polyesters derived from renewable eugenol and $\alpha, \omega$-diols via a continuous overheating method. Polymer Chemistry 6(40): 7138-7148.

Hu, K., Zhao, D., Wu, G. \& Ma, J. 2015b. Polyesters derived from bio-based eugenol and 10-undecenoic acid: Synthesis, characterization, and structure-property relationships. RSC Advances 5(105): 85996-86005.

Jankauskaite, V., Macijauskas, G. \& Lygaitis, R. 2008. Polyethylene terephthalate waste recycling and application possibilities: A review. Mater Sci (Medžiagotyra) 14(2): 119-127.

Khalil, A.A., ur Rahman, U., Khan, M.R., Sahar, A., Mehmood, T. \& Khan, M. 2017. Essential oil eugenol: Sources, extraction techniques and nutraceutical perspectives. RSC Advances 7(52): 32669-32681.

Labarrios, F., Garduño, L., Vidal, M.D.R., Garcia, R., Salazar, M., Martinez, E., Diaz, F., Chamorro, G. \& Tamariz, J. 1999.
Synthesis and hypolipidaemic evaluation of a series of $\alpha$-asarone analogues related to clofibrate in mice. Journal of Pharmacy and Pharmacology 51(1): 1-7.

Nabil, H., Ismail, H. \& Rashid, A.A. 2012. Effects of partial replacement of commercial fillers by recycled poly (ethylene terephthalate) powder on the properties of natural rubber composites. Journal of Vinyl and Additive Technology 18(2): 139-146.

Nadkarni, V.M. 2002. Recycling of polyesters. In Handbook of Thermoplastic Polyesters: Homopolymers, Copolymers, Blends, and Composites, edited by Fakirov, S. Weinheim: Wiley-VCH. Vol. 2. pp. 1221-1249.

Maulidan Firdaus* \& Atmanto Heru Wibowo

Research Group of Synthesis and Material Functionalization Universitas Sebelas Maret

J1. Ir. Sutami 36A Surakarta 57126

Indonesia

Triana Kusumaningsih

Department of Chemistry, Faculty of Mathematics and Natural Sciences

Universitas Sebelas Maret

J1. Ir. Sutami 36A Surakarta 57126

Indonesia

Carissa Hertiningtyas

Department of Chemistry, Graduate School

Universitas Sebelas Maret

J1. Ir. Sutami 36A Surakarta 57126

Indonesia

*Corresponding author; email: maulidan@mipa.uns.ac.id

Received: 5 November 2019

Accepted: 13 May 2020 